\title{
65 \\ VIBRATIONAL ANALYSIS OF UNFIRED HORIZONTAL BAYONET TUBES IN A FLUIDIZED BED CALCINER
}

S. D. Anderson and G. W. Hirschi

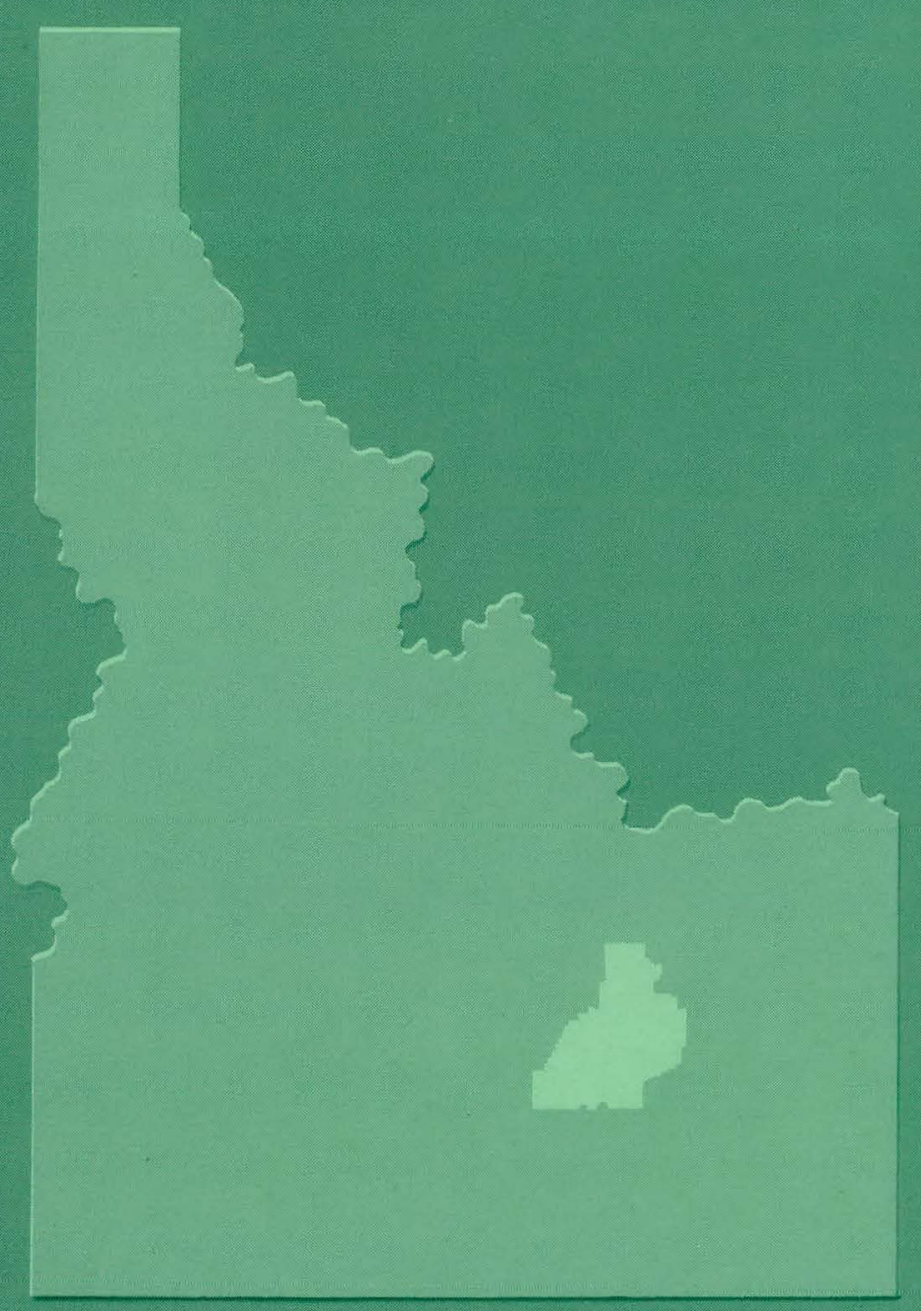

\section{PHILLIPS PETROL COMPANY}

NATIONAL REACTOR TESTING STATION US ATOMIC ENERCY COMMISSION 


\section{DISCLAIMER}

This report was prepared as an account of work sponsored by an agency of the United States Government. Neither the United States Government nor any agency Thereof, nor any of their employees, makes any warranty, express or implied, or assumes any legal liability or responsibility for the accuracy, completeness, or usefulness of any information, apparatus, product, or process disclosed, or represents that its use would not infringe privately owned rights. Reference herein to any specific commercial product, process, or service by trade name, trademark, manufacturer, or otherwise does not necessarily constitute or imply its endorsement, recommendation, or favoring by the United States Government or any agency thereof. The views and opinions of authors expressed herein do not necessarily state or reflect those of the United States Government or any agency thereof. 


\section{DISCLAIMER}

Portions of this document may be illegible in electronic image products. Images are produced from the best available original document. 


\section{PRICE $\$ .75$}

\section{Available from the Office of Technical Services \\ U.S. Department of Commerce \\ Washington 25, D. C.}

\section{LEGAL NOTICE}

This report was prepared as an account of Government sponsored work. Neither the United States, nor the Commission, nor any person acting on behalf of the Commission:

A. Makes any warranty or representation, express or implied, with respect to the accuracy, completeness, or usefulness of the information contained in this report, or that the use of any information, apparatus, method, or process disclosed in this report may not infringe privately owned rights; or

B. Assumes any liabilities with respect to the use of, or for damages resulting from the use of any information, spparatus, method, or process disçlused in llis tẹnnt.

As used in the above, "person acting on behalf of the Commission" includes any employee or contractor of the Commission, or employee of such contractor, to the extent that such employee or contractor of the Commission, or employee of such contractor prepares, disseminates, or provides access to, any information pursuant to his employment or contract with the Commission, or his employment with such contractor. 




IDO-16794

AEC Research and Development Report Engineering and Equipment TID-4500 (17th Ed.)

Issued: October 19, 1962

\section{Vibrational Analysis of Unfired \\ Horizontal Bayonet Tubes in a \\ Fluidized Bed Calciner}

\section{By}

S. D. Anderson

G. W. Hirschi

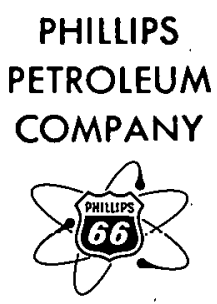

Atomic Energy Division

Contract AT(10.1)-205

Idaho Operations Office

U. S. ATOMIC ENERGY COMMISSION 
Vibrational Analysis of Unfired

Horizontal Bayonet Tubes in a

Fluidized Bed Calciner

S. D: Anderson

G. W. Hirschi

\section{$\underline{A} \underline{B} \underline{S} \underline{T} \underline{R} \underline{A} \underline{\mathrm{C}} \underline{\underline{T}}$}

The heat exchanger of the calciner consists of a vessel into which unfired, horizontal, bayonet tubes extend in a fluidized bed. Strain measurements were taken on several of the tubes under simulated operating conditions and the associated dynamic stresses were calculated.

Vibrations greater than design limitations for indefinite operation were found to exist. To restrict these vibrations and prevent further tube fatigue cracking, a tube support was installed. Since the installation of the support; the calciner has operated satisfactorily over 1275 hours as of June 28, 1962 . 
THIS PAGE

WAS INTENTIONALLY

LEFT BLANK 
I. Introduction . . . . . . . ........ 5

II. Description of Equipment . . . . . . . ..... 6

A. NaK Calciner............... 6

B. Strain Gauges. . . . . . . . . . . . . . 6

C. Thermocouples. . . . . . . . . . . . . . 7

D. Strain Gauge Calibration . . . . . . . . . . 7

III. Description of Tests . . . . . . . . . . . 8

IV. Results. . . . . . . . . . . . . . . 8

V. Conclüsions. .................. 10

VI. Addendum .. . . . . . . . . . . . . . . 10

VII. Appendix . . . . . . . . . . . . . . . . 12

VIII. References . . . . . . . . . . . . . . . 16

IX. Acknowledgement. . . . . . . ......... . 17

\section{$\underline{I} \underline{I} \underline{\mathrm{T}} \underline{\mathrm{O}} \underline{\mathrm{F}} \underline{\mathrm{F}} \underline{\mathrm{I}} \underline{\mathrm{G}} \underline{\mathrm{U}} \underline{\mathrm{R}} \underline{\mathrm{E}} \underline{\mathrm{S}}$}

Page

Figure IA Sketch of NaK Calciner . . . . . . . . . . 22

Figure IB Calciner Tube Details... . . . . . . . . . . 23

Figure 2 Calciner Vessel Strain Gauge Installation. . . . . 24

Figure 3. Close-up of Strain Gauge Installation. . . . . . 25

Figure 4 Strain Gauge Integral Lead Gland . . . . . . . . 26

Figure 5 Strain Gauge Bridge Circuit. . . . . . . . . . . 27

Figure 6 Oscillograph Traces Showing the Effect of the Fluidized Bed, Temperature and Air Flow on Tube Strain................... 28

Figure 7 Temperature vs. Vibration Intensity for a Strain Range of 186-248 $\mu$ in/in. . . . . . . . . . 29

Figure 8 Temperature vs. Vibration Intensity for a Strain Range of 248-372 $\mu$ in/in. . . . . . . . . . 30

Figure 9 Air Flow vs. Vibration Intensity for a Strain Range of $124-248 \mu$ in/in at $140^{\circ} \mathrm{F}$......... 31

Figure 10 Air Flow vs. Vibration Intensity for a Strain Range



Figure 11 Design Fatigue Strength Curve for $950^{\circ} \mathrm{F}$ Thbe Temperature. . . . . . . . . . . . . . 33

Figure 12 Fatigue Diagram for $950^{\circ} \mathrm{F}$ Tube Temperature... . . 34 


\section{$\underline{L} \underline{I} \underline{\mathrm{S}} \underline{\mathrm{T}} \underline{\mathrm{O}} \underline{\mathrm{F}} \underline{\underline{T}} \underline{\mathrm{A}} \underline{\mathrm{B}} \underline{\mathrm{L}} \underline{\mathrm{E}} \underline{\mathrm{S}}$}

Page

Table I. . Summary of NaK System Operation to October 5,

1961 . . . . . . . . . . . . 18

Table II. Outline of Test Conditions . . . . . . . . . . . . . 19

Table III. Summary of NaK System Operation Following Installation of Tube Support. . . . . . . . . . 20

Table IV. Results of 32,000 SCFH Flow and $950^{\circ} \mathrm{F}$ Tube Temper-

ature..................... . 21

Table V. Results of 17,000 SCFH Flow and $950^{\circ}$ F Tube Temper-

ature...................... . 2l 
I. Introduction

An international effort is currently in progress to perfect a truly satisfactory radioactive waste disposal method which combines the necessary degree of radiological safety with favorable economics. Of the many processes under development, the facility at the ICPP was built to demonstrate the adaptability of the fluidized bed for reducing radioactive wastes to solids. Previous laboratory and pilot plant programs had demonstrated the feasibility of the calcination process and a large scale plant would demonstrate its operability and provide for the development of additional process and equipment design data.

Several possible methods of heating the calciner were considered. Electric heating elements used in pilot plant tests resulted in unusually short service life, and remote replacement of defective elements would be virtually impossible. Direct f'iring would have required an excessively large diameter calciner. The indirect heat transfer method of heating was therefore considered the most suitable for the calcination unit. The heat exchanger consists of a vertical vessel into which extend unfired, horizontal, bayonet type tubes. The outer tubes are of double wall construction to permit helium gas monitoring for leak detection.

For the high temperature levels involved, a liquid metal heat transfer medium was required. The eutectic sodium-potassium ailoy was chosen in preference to sodium because of its liquidity at room temperature.

After 772 hours of operation, a helium leak occurred on October 5, 1961, in the second tube from the top of row "AA" (Figs. $I A$ and $I B$ ) of the NaK calciner tube bundle. Prior to the leak the system had been started up 13 times and was operated for 460 hours below $1100^{\circ} \mathrm{F}$ and for 312 hours above $1100^{\circ} \mathrm{F}$. These temperatures were measured at the furnace outlet; and, therefore, the tube temperatures would be somewhat less (approximately $75-125^{\circ} \mathrm{F}$ ). A summary of the calciner operating history is given in Table $I$.

The leak was due to a circumferential crack around the bottom half of the outer tube approximately 3/4" from the tube sheet weld. The tube was repaired by welding a $1-7 / 8$ " long sleeve of $11 / 2 "$ diameter, Schedule 40, Type 316 SS pipe over the break. One weld was to the tube sheet and the other to the tube.

The system was brought to operating temperature on October 13, 1961, and on October 18, another leak developed in the same tube. This leak was due to circumferential cracking around the top half of the tube adjacent to the sleeve weld. The faulty tube was then completely encased in another tube which was welded to the tube sheet and secured at the free end to permit only horizontal expansion and contraction. 
The system was again brought to operating temperature and operated until the last of. November. An internal inspection revealed that the welded support rod had been torn from the shell of the calciner. Although both failures. were on the same tube, the sheared support rod indicated the probability of considerable external forces rather than a failure due to a faulty tube. It was therefore decided that a fatigue stress analysis should be performed to determine the probable cause of failure.

II. Description of Equipment

A. NaK Calciner

The calciner, Fig. IA, consists essentially of a vertical vessel with cone bottom and hemispherical top head. A heat exchanger tube bundle is inserted horizontaily through the shell from the side into the fluidized bed. The feed stream, a radioactive aqueous solution of aluminum nitrate and nitric acid, is introduced into the fluidized bed near the mid-point of the vessel. Heated NaK flows through the tubes and provides heat to convert the solution into a dry granulated solid of aluminum oxide. The bed is kept in a fluid. state by the upward movement of preheated air which is introduced in the bottom of the vessel and distributed through the cross section of the vessel by means of a perforated grid plate. The grid plate is located below the heating tube bundle.

\section{B. Strain Gauges}

Consideration of potential failure mechanisms led to the conclusion that strain gauges and thermocouples could best be employed. Strain gauges were attached to the tube at a distance of $1 / 4$ " from the tube taper. The weldable, stainless steel clad, mineral oxide insulated Microdot Type $\mathrm{C}$ gauges with integral leads were chosen. These gauges were not compensated for the effects of apparent strain caused by temperature changes. As a matter of convenience, nine out of ten gauges were A-C coupled, which prevented the display of information caused by apparent strain due to temperature change; and, therefore, these nine gauges measured only dynamic strain. The other gauge was $D-C$ coupled and did display effects caused by temperature change. The gauges were $9 / 16^{\prime \prime}$ long and $1 / 8$ " wide. The active dimensions were somewhat less. The gauges were oriented is such a fashion as to measure longitudinal strain only. A total of ten gauges were mounted on five accessible tubes which were of four different lengths. One gauge was mounted on the top of each instrumented tube, and one on the side. (Figs. 2 and 3.)

Leadout of the electrical connections (three glass insulated wires in a $3 / 32^{\prime \prime}$ stainless steel tube) was accomplished through a specially fabricated gland installed in an unused injection port. (Fig. 4.) 
The actual installation was performed under very difficult conditions. Attachment of the gauges was at a point near the tube sheet under a projecting lip of the $4 \mathrm{ft}$. diameter calciner vessel.

A terminal connection board was installed in the calciner cell, upon which electrical connections were made to the $120 \mathrm{ft}$. run of instrumentation cable connecting the gauges to the instrumentation console.

Instrumentation console equipment consisted of ten strain gauge power supplies, ten strain gauge balance, completion and coupling networks, ten Video 721 low level D-C amplifiers, ten galvanometer current driver amplifiers, a CEC recording oscillograph, and other required measurement and calibration equipment. (Fig. 5.)

c. Thermocouples

Five Chromel-Alumel thermocouple pairs were resistance welded at 3 " intervale to the calciner NaK monitoring chamber barrel. Glass insulated wire was carried to the calciner Plant Operations corridor where these thermocouples were read out on a portable potentiometer.

\section{Strain Gauge Calibration}

In calculating strain versus load for calibration of the strain gauges, a distance (48.5") from the shell side of the tube sheet to the point of load application was chosen which would be applicable for every length of tube and convenient for applying the load. The outer and inner tubes were considered as one solid cantilever fixed at the tube sheet. It will be noted from the calculations (Appendix II.A) that the effect of the core tube was essentially negligible. The maximum load (6I.5 lbs.) to be applied when calibrating the strain gauges was chosen to provide a reasonable deflection on the galvanometer and yet would prevent a high stress from being applied to the tube neck.

By means of a spring scale and weights, various loads were applied to each instrumented tube and the galvanometer deflections were noted. The galvanometer deflections observed during strain gauge calibration agreed with calculated values to within the accuracy limits with which calibrating forces could be applied.

Following the calibration of the gauges, the tubes on which the strain gauges were mounted were vibrated as a check on the gauge instrumentation. All instrumentation associated with each gauge appeared to be functioning properly. 


\section{Description of Tests}

In order to segregate possible sources of calciner tube vibration and determine what effects there were with changing conditions, the following series of tests were made with variations in flow, temperature and bed.

A. Prior to Pouring in the Alumina Bed

1. The NaK flow was varied while there was no air flow.

2. The air flow was varied while there was no NaK flow.

B. After the Addition of the Fluidized Bed

1. The NaK flow was varied while the air flow and NaK temperature were held constant.

2: The air flow was varied while the NaK flow and temperature were held constant.

3. The NaK temperature was varied while the NaK flow and air flow were held constant.

4. The air flow was varied while the NaK flow and temperature were held constant. (NOTE: This was at temperatures of $950^{\circ} \mathrm{F}$, whereas Item 2 was at $140^{\circ} \mathrm{F}$.)

An outline of the test conditions are given in Table II.

When a NaK inlet temperature of $950^{\circ} \mathrm{F}$ was reached, five of the ten gauges failed within a few minutes. Later contact with the vendor revealed this to be the result of a brazed electrical contact failure within the strain gauge. The strain gauge is otherwise capable of ' $1500^{\circ} \mathrm{F}$ operation.

\section{Resulte}

A review of the oscillograph strip charts following the termination of the test revealed the following:

A. Without the fluidiżed bed there was no indication of vibrations on the tubes when either NảK or air was flowing. (Fig. 6A.)

B. As soon as the bed was added to the calciner, vibrations of small magnitude were observed. However, there was no observable change in magnitude or frequency when the NaK flow was changed and the other parameters held constant. (Fig. 6B.) 
C. When either the air flow or temperature was altered, there was a marked change in the magnitude of the vibrations-increasing at the higher air flows and temperatures. (Figs. 6C,6D,6E and 6F.)

From the oscillograph recordings information was obtained from which curves showing the effects of temperature and air flow on cycling strain were plotted (Figs. 7,8,9 and 10). In determining the average cycles per second for a specific strain range, intervals of 40-90 seconds of strip chart length were used.

In determining allowable operating times for values of vibration stresses obtained from the tests, reference was made to Report PB 151988 "Tentative Structural Design Basis for Reactor Pressure Vessels and Directly Associated Components". There will be no attempt to cover the entire method of determining allowable stress cycles as outlined in this report. This report includes design criteria for cycling stresses based on allowable mean stress intensity for fatigue evaluation and allowable amplitude for alternating stress intensity. For a limiting number of cycles the report draws attention to an accumulative usage factor which merely adds an additional factor of safety to the allowable operating life.

In determining the basic mean stress $\left(S^{\prime}{ }^{\prime}\right.$ ) the temperature differential between the monitoring chamber marrel and the tube temperature was used. The monitoring chamber barrel temperature was obtained from the five thermocouples welded to the barrel and the tube temperature was considered to be equivalent to the NaK inlet temperature (the two thermocouples originally installed on the tubes were considered unreliable). The temperature differential between the tubes and the barrel was approximately $200 \%$ which would result in a stress of $50 \times 10^{3}$ psi for the worst conditions (i.e., slippage between the tube sheet and inner tube but no slippage between the inner and outer tubes). For this assumption, $S^{r}$ plus the alternating stress ( $S_{a l t}$ ) is greater than the elastic mimit $\left(S_{b}\right)$; therefore, $S_{\text {man }}=\mathrm{S}_{\mathrm{b}}{ }^{\mathrm{a} t} \mathrm{~S}_{\text {alt }}$ (Reference 1, Page 29). The adjusted mean stress ( $\left.S_{\text {mean }}\right)$ is used on the Fatigue Diagram, Fig. 12.

In the Fatigue Diagram, Fig. 12, it is seen that stresses were obtained in the tests that exceeded the design limits (dashed line) for infinite cycle operation. The allowable operating time for the calciner at $950^{\circ} \mathrm{F}$ and $32,000 \mathrm{SCFH}$ was determined and found to be 15 hours. For conditions of $950^{\circ} \mathrm{F}$ and $17,000 \mathrm{SCFH}$, the allowable operating time was 555 hours. These calculations are based on a considerable margin of safety and, therefore, it is not surprising that the calciner was operated for 772 hours before a tube failed.

To prevent exceeding the safe operating limits for indefinite operation for a mean stress intensity of 21,600 psi, the tube neck alternating stress intensity must not exceed 9,400 psi, which is equivalent to a cycling strain of $280 \mu \mathrm{in} / \mathrm{in}$. By referring to 
Fig. 10, it may be assumed that for $950^{\circ} \mathrm{F}$ tube temperature, stresses greater than $280 \mu \mathrm{in} /$ in would disappear when the air flow was reduced to 12,000 SCFH.

V. Conclusions

Vibrations above allowable design limits appear to be obtainable when operating the calciner above $950^{\circ} \mathrm{F}$ and $12,000 \mathrm{SCFH}$. Since the calciner was operated for over 300 hours above these conditions, this seems to be a feasible answer to the tube failures.

The data indicates that this vibration is caused by the velocity of air flow through the fluidized bed. By changing the air velocity through the bed either by increasing the air flow or by heating the tubes; there is a marked change in vibration magnitude. In order for the calciner tubes to have an unlimited life span with regard to vibration damage, the existing system will have to be operated at a maximum $\mathrm{NaK}$ temperature of $950^{\circ} \mathrm{F}$ and a maximum air flow of $12 ; 000 \mathrm{SCFH}$. If it. is desirable to have a higher operating temperature, then the air flow must be reduced to maintain a constant average air velocity through the bed. If the air flow is increased above. 12,000 SCFH, the tube temperature must be lowered.

To operate the calciner at temperatures and flows greater than the conditions stated above for an indefinite length of time, the tubes should be fastened near the f'ree end to prevent or limit vibration. An investigation of flow patterns through the fluidized bed might also be desirable as a possibility of dampening the vibration of the calciner tubes.

VI. Addendum

On completion of the analysis of the data obtained in the tests, it was concluded that a tube support structure should be installed. Since one tube had already failed, it was reasoned that the same mechanism which caused that failure could have weakened other tubes, which would then be on the verge of failure. It was, therefore, desired to know the condition of all other tubes before installing the tube support structure. The conventional methods of determining this condition, such as dye penetrant tests, were not suitable because limited access to the tube sheet made it impossible to conduct these tests. It was suggested that the resonant frequency of all tubes could be measured. The resonant frequency would be a function of the geometry and mass of the tube and the compliance at the point of attachment. Any condition which would lead to failure, such as an incipient crack near the tube sheet, would markedly increase the compliance of a given tube. This should decrease the resonant frequency of the tube and be readily observable.

A. fixture was manufactured to allow an accelerometer to be attached to the tip of each tube. The accelerometer signal was subsequently amplified, passed through a band pass filter and simultaneously displayed on an oscilloscope and measured with 
the Beckman EPUT meter. Oscillations were counted for a period of ten seconds. These measurements were repeated several times on each rod. Each rod was checked in both vertical and horizontal oscillation. All rods of the same length oscillated at substantialiy the same resonant frequency in both the horizontal and vertical mode. Thirtyeight of the forty-two rods in the tube bünde were checked. The shrouded tube was not checked. This test provided a reasonable assurance that all tubes in the bundle have retained their original integrity.

The tube support consisted of a series of twelve bars placed horizontally between each row of tubes. Grooves were machined in each bar into which the tubes were positioned. The bars were held together by twelve bolts running vertically between the tubes. The tube support was pinned to side brackets which were welded to the calciner vessel wall. The support was so pinned as to allow the tube bundle to move horizontally with changes of temperature.

With the tube support installed, the calciner was put into normal operation and strain gauge data was obtained from the five remaining gauges. The data indicated that nearly all the vibrating strain had been limited to less. than $62 \mu \mathrm{in} /$ in with some in the 62-186 $\mu$ in/in range. There was only one indicated strain in 15 minutes of chart data that was greater than the calculated maximum strain of $280 \mu \mathrm{in} /$ in for indefinite operation. This could have possibly been a malfunction of instrumentation since all of the gauges failed shortly after the test was started. However, assuming the strain was real and occurred every 15 minutes, the safe operating time would be 6,250 hours. This value is extremely conservative since this excessive indicated strain occurred only near the time the bed was added and there was not the slightest indication of excessive stresses during the high operating conditions.

Since the installation of the tube support, the calciner has operated satisfactorily at a temperature greater than $1100^{\circ} \mathrm{F}$ for over 1275 hours as of June 28, 1962. A summary of the calciner operating history following the installation of the tube support is given in Table III. 


\section{Appendix}

I. Nomenclature.

$c=$ distance from neutral axis to outside fiber (in.)

$E=$ modulus of elasticity (psi)

$I=$ moment of inertia (in. ${ }^{4}$ )

$\mathrm{L}=$ distance from point of stress to load (in.)

$\mathrm{n}=$ actual number of operation cycles

$\mathrm{N}$ = number of cycles required to produce an unsafe condition

$P=\operatorname{load}($ libs.)

$\mathrm{S}_{\mathrm{a}}=$ allowable amplitude of alternating stress intensity (psi)

$S_{\text {alt }}=$ calculatedi amplitude of alternating stress intensity (psi)

$S_{b}=$ elastic limit (psi)

$S_{\text {mean }}^{\prime}=$ basic value of calculated mean stress intensity (psi)

$\mathrm{S}_{\text {mean }}=$ adjusted value of mean stress intensity (psi)

$S_{S}=$ allowable mean stress intensity. for fatigue evaluation (psi)

$\mathrm{y}=\operatorname{deflection}($ in.)

$\alpha=$ coefficient of thermal expansion (in/in- ${ }^{\circ} F$ )

$\varepsilon=\operatorname{strain}($ in/in )

Subscripts

$$
\begin{aligned}
\mathrm{g} & =\text { strain gauge } \\
\mathrm{n} & =\text { tube neck } \\
\mathrm{ct} & =\text { core tube }
\end{aligned}
$$

\section{Strain Gauge Calibration}

A. Load versus strain for strain gauge calibration (inner and outer tubes were considered as a single cantilever beam.) 


$$
\begin{aligned}
& S=\frac{P C L}{I} \\
& \varepsilon=\frac{S}{E}=\frac{P c L}{I E}
\end{aligned}
$$

For 316 SS at $70^{\circ} \mathrm{F} \dot{\varepsilon}=28 \times 10^{6}$, at $950^{\circ} \mathrm{F} \dot{\varepsilon}=24 \times 10^{6}$

$$
\begin{aligned}
& I=0.049087\left(D_{0}^{4}-D_{i}^{4}\right) \\
& I_{n}=(0.049087)\left[(1.52)^{4}-(1.086)^{4}\right]=0.193 \\
& I_{g}=(0.049087)\left[(1.54)^{4}-(1.086)^{4}\right]=0.208 \\
& \varepsilon_{g}=\frac{(.77)(47.75) P_{1}}{(.208)(28 \times 10}=6.32 \times 10^{-6} \mathrm{P} \\
& \left.\varepsilon_{n}=\frac{(.76)(48.5)}{(.193)(28 \times 10} 6\right)=6.82 \times 10^{-6} \mathrm{P}
\end{aligned}
$$

Let $P=60 \mathrm{lbs}$.

Then $\varepsilon=379 \mu$ in $/$ in

$$
\begin{aligned}
& y=\frac{P L^{3}}{3 E I} \\
& y=\frac{(60)(47.75)^{3}}{(3)\left(28 \times 10^{6}\right)(.208)}=.374 \mathrm{in} .
\end{aligned}
$$

Deflection of core tube $=.374-.114=.260$

(Note that the core tube dimension was estimated since it was not on the drawings)

$$
\begin{aligned}
& P_{c t}=\frac{3 y E I}{I} \\
& I_{c t}=(.049087)\left[(.758)^{4}-(.614)^{4}\right]=0.00907 \\
& P_{c t}=\frac{(3)(.26)\left(28 \times 10^{6}\right)(.00907)}{(47.75)^{3}}=1.81 \mathrm{~b} .
\end{aligned}
$$

Total load for $379 \overline{\mu i n} /$ in strain $=61.8 \mathrm{lb}$.

B. Galvonameter Reading

Galvo Gain Stress Per 1.00 inch of Galvo Deflection 
III. Results from Data

A. Static stress on tubes (assuming worst condition - no slipage between inner and outer tubes).

Tube wall temperature $=900^{\circ} \mathrm{F}$

Shell wall temperature $=700^{\circ} \mathrm{F}$

Tube wall $\triangle \mathrm{T}=200^{\circ} \mathrm{F}$

Static stress $\left(S^{\prime}{ }_{\text {mean }}\right)=\varepsilon_{S} \mathrm{E}=\Delta \mathrm{T} \alpha_{\mathrm{E}}$

$$
\begin{aligned}
& =(200)\left(10.4 \times 10^{-6}\right)\left(24 \times 10^{6}\right) \\
& =50 \times 10^{3} \mathrm{psi}
\end{aligned}
$$

B. Alternating Stress ( $\mathrm{S}_{\text {alt }}$ ) During Operation

The maximum galvanometer deflection was $1 / 2$ inch at a gain setting of 200 .

$$
\begin{aligned}
& \varepsilon_{\mathrm{g}}=(.5)(1240)=620 \mu \mathrm{in} / \mathrm{in} \\
& \mathrm{S}_{\text {a.lt }}=\mathrm{K} \varepsilon_{\mathrm{g}} \mathrm{E} \\
& K=\text { the product of the location factor }\left(K_{L}\right) \text { - con- } \\
& K=\left(K_{L}\right)\left(K_{S}\right)=(1.08)(1.3)=1.4 \\
& S_{\text {alt }}=(1.4)\left(620 \times 10^{-6}\right)\left(24 \times 10^{6}\right)=20.9 \times 10^{3} \text { psi }
\end{aligned}
$$

Miner's Hypothesis:

$$
\mathrm{U}=\frac{\mathrm{n}_{1}}{\mathrm{~N}_{1}}+\frac{\mathrm{n}_{2}}{\mathrm{~N}_{2}^{2}}+\cdots \cdots \cdot+\frac{\mathrm{n}}{\mathrm{N}_{\mathrm{n}}}
$$

NOTE: For unlimited operation, the cumulative usage factor

$(U)$ in Miner's Hypothesis should not exceed 0.80 . 
Using the calculated data from Table IV:

$$
\mathrm{U}=\frac{\mathrm{n}_{1}}{N_{1}}+\frac{\mathrm{n}_{2}}{N_{2}}+\cdots \cdot \frac{\mathrm{n}_{\mathrm{n}}}{\mathrm{N}_{\mathrm{n}}}
$$

Let $H=$ totail hours of safe operation

$$
\begin{gathered}
0.8=\frac{75 \mathrm{H}}{1.9 \times 10^{4}}+\frac{452 \mathrm{H}}{2.8 \times 10^{2}}+\frac{1580 \mathrm{H}}{5.2 \times 10^{2}} 4+\frac{\mathrm{n}}{\infty} \\
\mathrm{H}=15.8 \text { Hours }
\end{gathered}
$$

Using the calculated data from Table V:

$$
\begin{aligned}
0.8= & \frac{75 \mathrm{H}}{5.2 \times 10^{4}} \\
& H=555 \text { Hours }
\end{aligned}
$$

From Figure 12 it will be noted that alternating stress values below" $9,400 \mathrm{psi}$ (280 $\mathrm{\mu in} /$ in strain) will allow an unlimited number of 'cycles. 


\section{References}

1. Macqueen, D. K. and Stevens, J. I., "Design Bases for ICPP Waste Calcination Facility," IDO-14462, April 22, 1959.

2. Office of Technical Services, United States Department of Commerce, "Tentative Structural Design Basis for Reactor Pressure Vessels and Directly. Associated Components," PB 151987, December 1, 1958.

3. The Griscom-Russell Company, Dwg. No. E-6467, Rev. D, "Assembly Detail for \#42-12 -51 DSP Tube Bundle, "June 16, 1959.

4. The Griscom-Russell Company, Dwg. No. E-6393, Rev. E, "Duplex

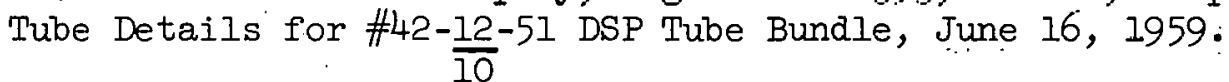

5. Phillips Petroleum Company, Dwg. No. CPP-E-2589, Rev. 2, "NaK Tube Bundle Support Assembly Drawing, February 23, 1962. 


\section{ACKNOWLEDGEMENT}

The authors wish to acknowledge the efforts of E. S. Brown, J. I. Stevens and G. E. Lohce for their valuable suggestions and assistance throughout the test, analysis and concluding report. Also, special recognition is given to W. L. Fouts for his skillfull welding of the strain gauges in an extremely cramped and undesirable atmosphere. The extra efforts of the CPP Operations personnel who followed the tests are likewise appreciated. 
TABLE I

SUMMARY OF INAK SYSTEM OPERATION TO OCTOBER 5, 1961

\begin{tabular}{|c|c|c|c|c|c|c|}
\hline $\begin{array}{l}\text { STARTUP } \\
\text { NUMBER } \\
\end{array}$ & DATE & $\begin{array}{l}\text { MAXIMUM RATE OF } \\
\left.\text { RISE (Furnace) }{ }^{\circ} \mathrm{F}\right)\end{array}$ & $\begin{array}{c}\text { MAX. TEMPERATURE } \\
\text { ATTAINED ( }\left({ }^{\circ} \mathrm{F}\right) \\
\text { (NaK. Furnace Outlet) } \\
\end{array}$ & $\begin{array}{c}\text { MAYIMUM } \\
\text { FLUCCIUATION } \\
\text { AFTER STARTUF }\left({ }^{\circ} \mathrm{F}\right) \\
\end{array}$ & $\begin{array}{l}\text { HRS. BELOW } \\
\quad 1100^{\circ} \mathrm{F} \\
\end{array}$ & $\begin{array}{l}\text { HRS. ABOVE } \\
1100^{\circ} \mathrm{F} \\
\end{array}$ \\
\hline 1 & $1 / 6 / 61$ & - & 932 & - & 2 & 0 \\
\hline 2 & $1 / 10 / 61$ & - & 518 & $\begin{array}{l}\text { Cooled } 518 \text { to } 122 \\
\text { in } 7 \text { hours }\end{array}$ & 8 & 0 \\
\hline 3 & $1 / 13 / 61$ & - & 176 & - & 1 & 0 \\
\hline 4 & $\begin{array}{l}1 / 16 / 61 \\
1 / 17 / 61\end{array}$ & & $\begin{array}{l}626 \\
914\end{array}$ & $\begin{array}{l}\text { Cooled } 293 \text { in } \\
2 \text { hours }\end{array}$ & 40 & 0 \\
\hline 5 & $1 / 24 / 61$ & - & 572 & - & 3 & 0 \\
\hline 6 & $2 / 5 / 61$ & 284 in lst hour & 1076 & - & 26 & 0 \\
\hline 7 & $3 / 15 / 61$ & 518 in lst hour & 626 & - & 10 & 0 \\
\hline 8 & $3 / 21 / 61$ & 392 in Ist hour & 662 & - & 3 & 0 \\
\hline 9 & 4/10/61 & 464 in Isti hour & 1148 & - & 20 & 3 \\
\hline 10 & $4 / 11 / 61$ & 446 in Ist hour & 1067 & 230 in 75 mirutes & 40 & 0 \\
\hline 11 & $4 / 14 / 61$ & 374 in 3rd hour & 1094 & 212 in 15 minutes & $21-3 / 4$ & $9-3 / 4$ \\
\hline 12 & $5 / 18 / 61$ & 446 in Ist hour & 1256 & Cooled 329 in 1 hour & 254 & 129 \\
\hline 13 & $9 / 27 / 61$ & 365 in 2nd hour & 1301 & 338 in 70 minutes & 31 & 183 \\
\hline
\end{tabular}




\section{TABIE II}

\section{OUTLTNE OF TEST CONDITIONS}

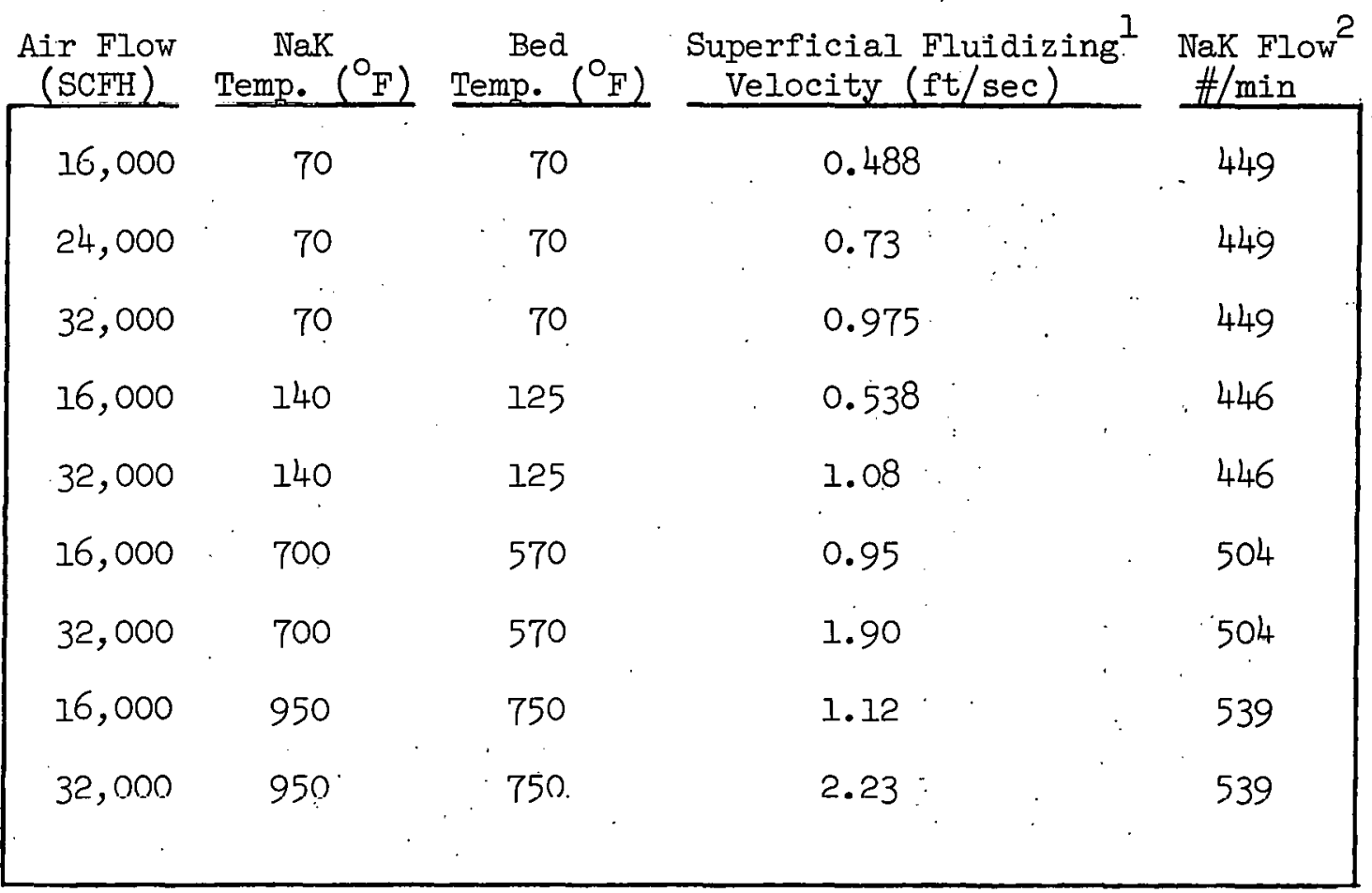

1. Superficial fluidizing velocity is determined at bed temperature and vessel pressure (constant at 10.75 psia) and is based on the empty cross-sectional area of the vessel (12.57 square feet).

2. Change in NaK flow was caused by temperature increase, change in NaK properties and change in pump efficiency. 


\section{TABLE IIT - SUMMARY OF NaK SYSTEM}

\section{FOLLOWING INSTALIATION OF TUBE :SUPPORT}

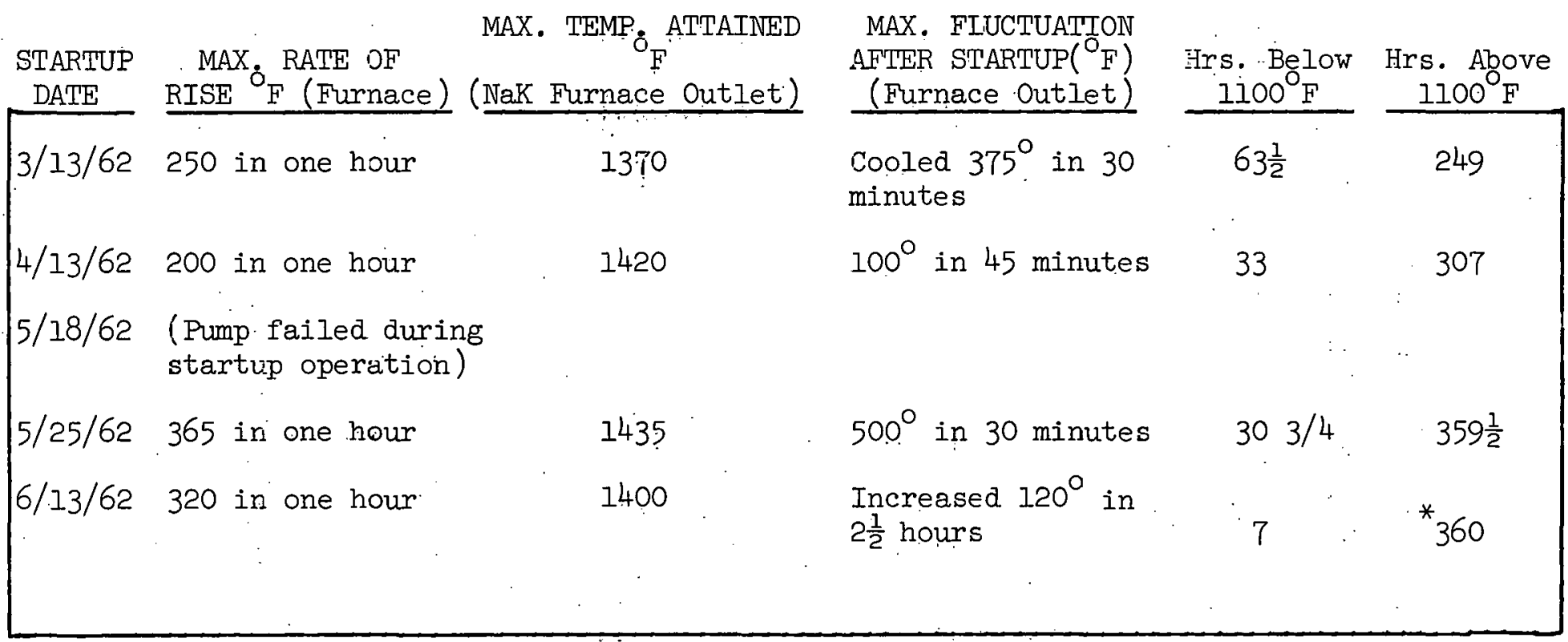

* This value is until 1700 hours on June 28, 1962. The calciner was still in operation above $1100^{\circ} \mathrm{F}$ at thị date. 
TABLE IV

RESULTS OF 32,000 SCFH FLOW AND $950^{\circ} \mathrm{F}$ TUBE TEMPERATURE

\begin{tabular}{|c|c|c|c|c|c|}
\hline $\begin{array}{c}\text { Strain } \\
-\mu \text { in/in }\end{array}$ & $\begin{array}{c}\text { Cycles } \\
\text { Per Hour }\end{array}$ & $\mathrm{psit}_{\mathrm{psi}}$ & $\begin{array}{c}S_{\text {mean }} \\
\text { psi }\end{array}$ & $\begin{array}{l}\mathrm{Sa}^{*} \\
\text { psi }\end{array}$ & $\begin{array}{c}\text { Allowable } \\
\text { Cycles }\end{array}$ \\
\hline 620 & 75 & 20,900 & 10,100 & 25,500 & $1.9 \times 10^{4}$ \\
\hline 496 & 452 & 16,700 & 14,300 & 22,600 & $2.8 \times 10^{4}$ \\
\hline 372 & 1580 & 12,500 & 18,500 & 18,800 & $5.2 \times 10^{4}$ \\
\hline 248 & & 8,340 & 22,660 & 14,100 & \\
\hline
\end{tabular}

TABLE_V

RESULTS OF 17,000 SCFH FLOW AIND $950^{\circ} \mathrm{F}$ TUBE TEMPERATURE

\begin{tabular}{|c|c|c|c|c|c|}
\hline $\begin{array}{l}\text { Strain } \\
-\mu \text { in/in }\end{array}$ & $\begin{array}{c}\text { Cycles } \\
\text { Per Hour } \\
\end{array}$ & $\begin{array}{l}\text { Salt }_{n} \\
\text { psi }\end{array}$ & $\begin{array}{l}\mathrm{S}_{\text {mean }} \\
\mathrm{psi} \\
\end{array}$ & $\begin{array}{l}\mathrm{Sa}^{*} \\
\mathrm{psi}\end{array}$ & $\begin{array}{c}\text { Allowable } \\
\text { Cycles }\end{array}$ \\
\hline .5 & 0 & - & - & - & - \\
\hline .4 & 0 & - & - & - & - \\
\hline$\cdot 3$ & 75 & 12,500 & 18,500 & 18,800 & $5.2 \times 10^{4}$ \\
\hline
\end{tabular}

*alues of $S_{a}$ were obtained by plotting $S_{a l t}$ and $S_{\text {mean }}$ on the Fatigue Diagram (Fig. 12) and drawing a line from the $\mathrm{S}_{\mathrm{s}}$ value through each plotted point until it intersects with the ordinate of the curve. The ordinate intersection is the $\mathrm{S}_{\mathrm{a}}$ for each.plotted point. Each $S_{a}$ value is then used on the Design Fatigue Strength Curve (Fig. Il) and the safe number of cycles are obtained. 


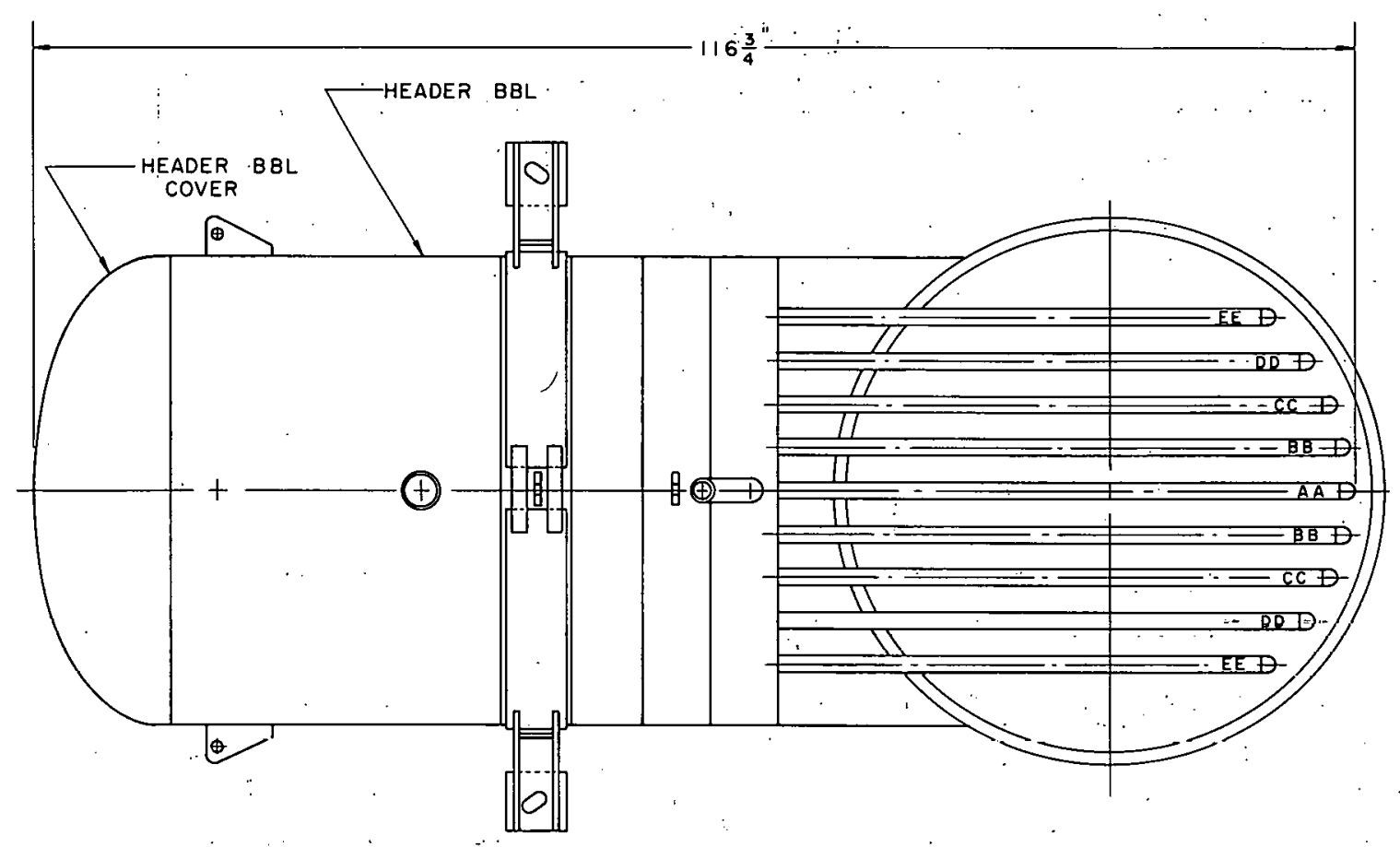

\section{PLAN VIEW.}



Fig. IA Sketch of $\mathrm{NaK}$ Calciner 




Fig. IB Details for NaK Calciner Sketch 


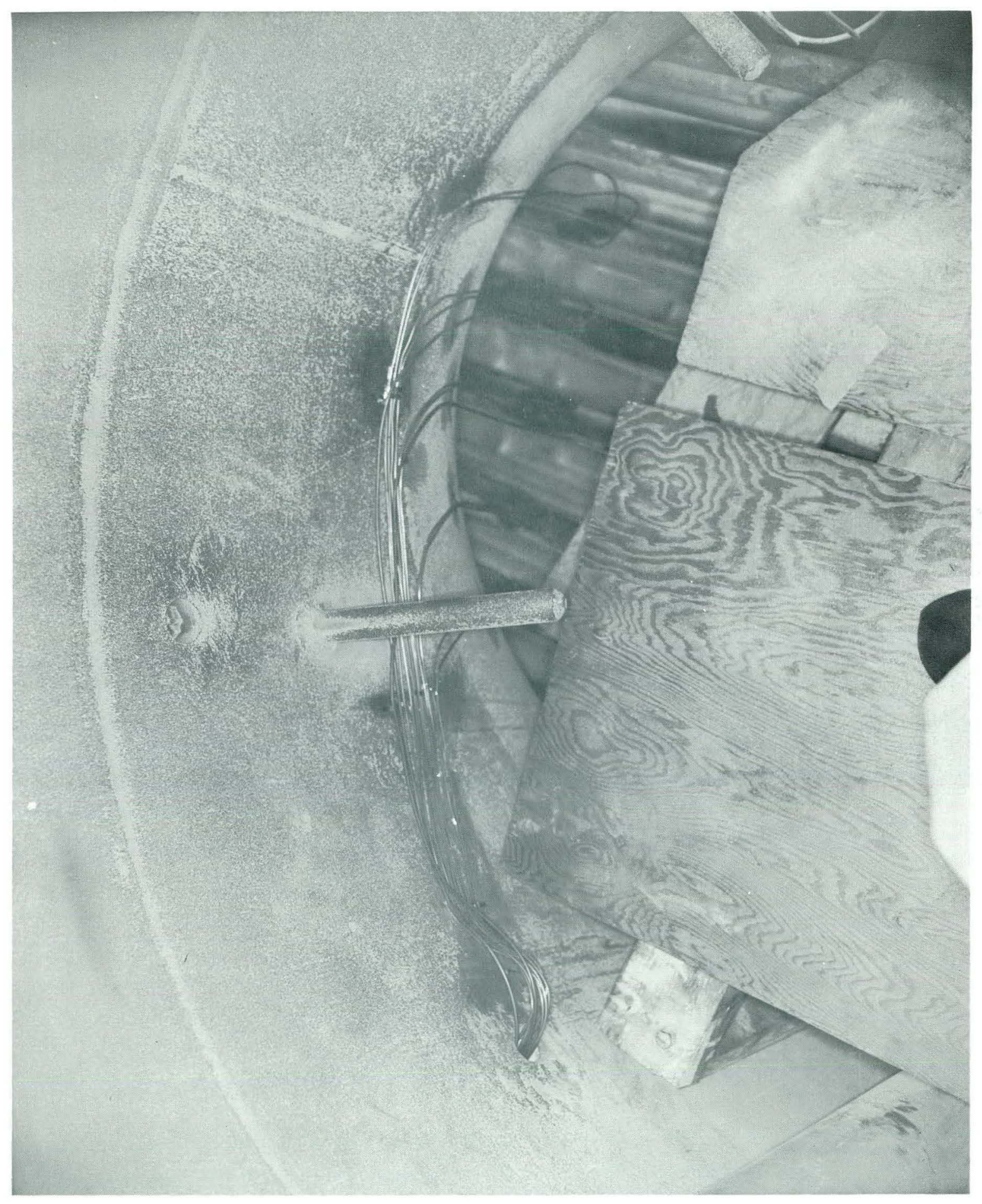

Fig. 2 Calciner Vessel Strain Gauge Installation 




Fig. 3 Close-Up of Strain Gauge Installation 


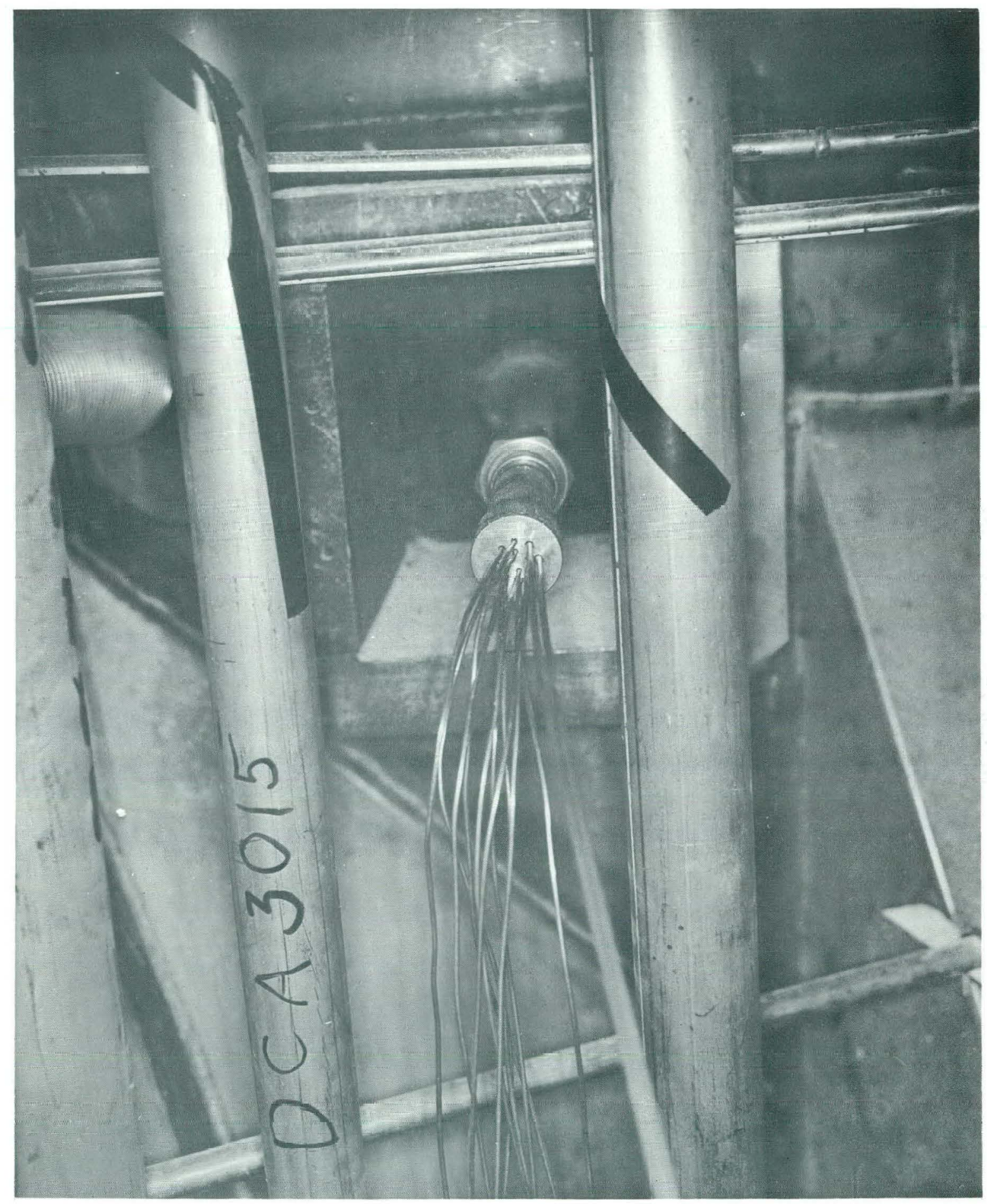

Fig. 4 Strain Gauge Integral Iead Gland 


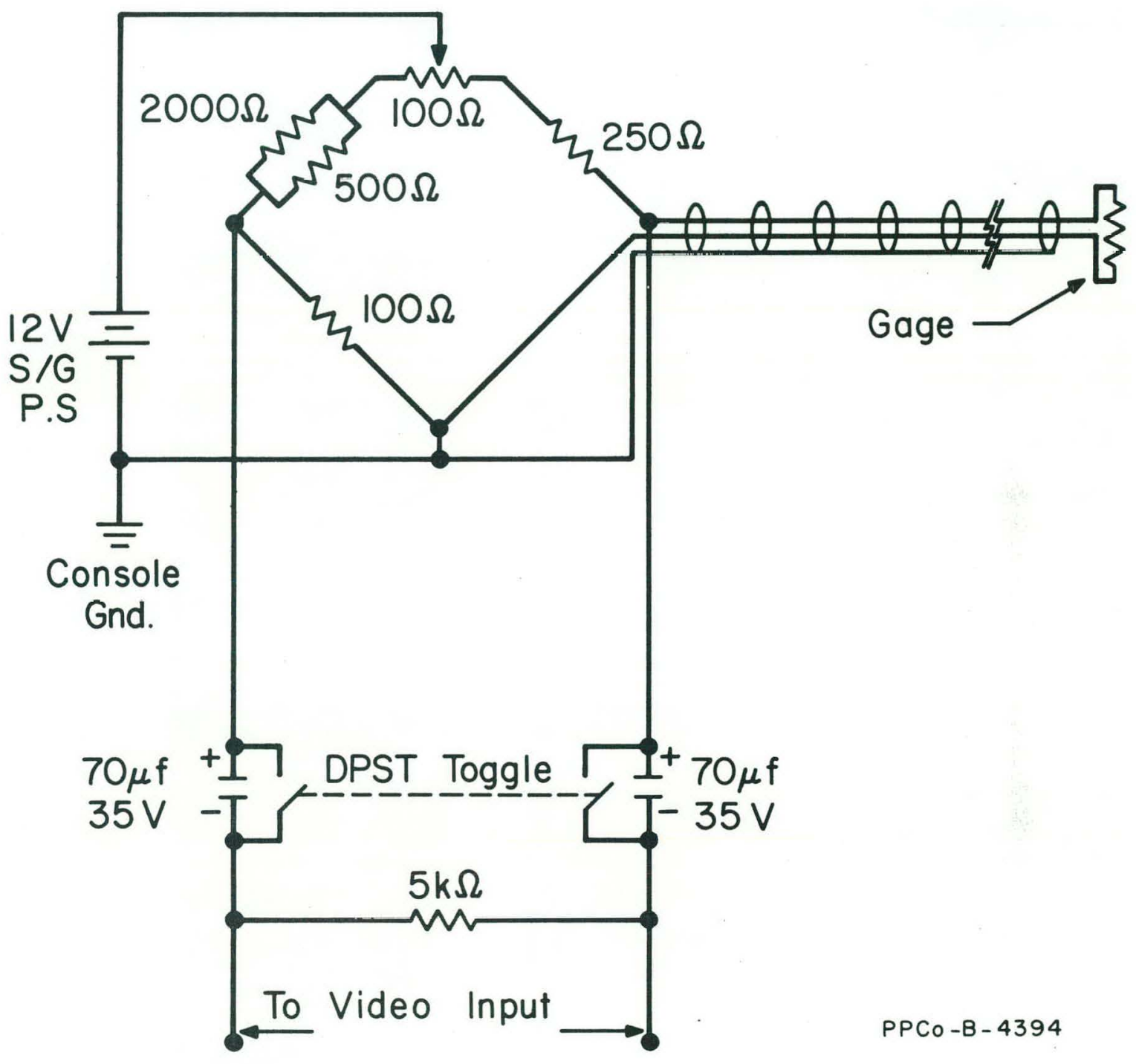

Strain Gage Bridge CKT

Fig. 5 


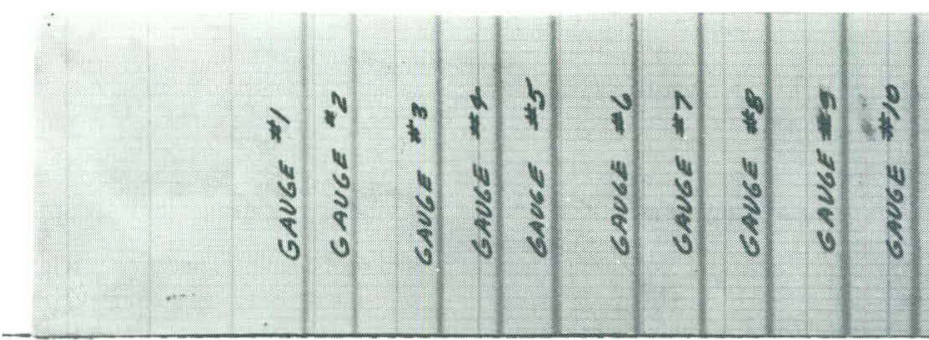

A. Without Bed

Air flow $=16,000$ SCFH

$\mathrm{NaK}$ temperature $=140^{\circ} \mathrm{F}$

NOTE: EVEN \# GAUGES WERE ON SIDES OF TUBES



C. NaK temperature $=140^{\circ} \mathrm{F}$ Air flow $=32,000 \mathrm{SCFH}$ With Bed

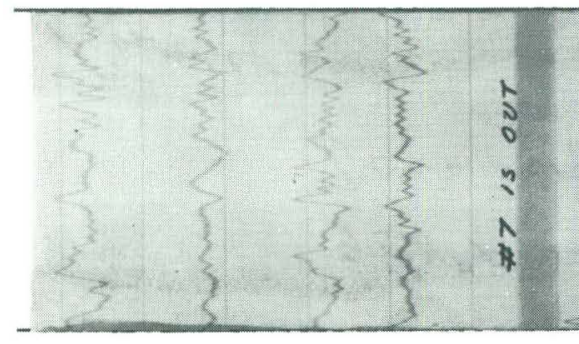

E. Air flow $=17,000$ SCFH $\mathrm{NaK}$ temperature $=950^{\circ} \mathrm{F}$ With Bed

$$
I^{\prime \prime}=1240 \mu \mathrm{in} / \mathrm{in}
$$

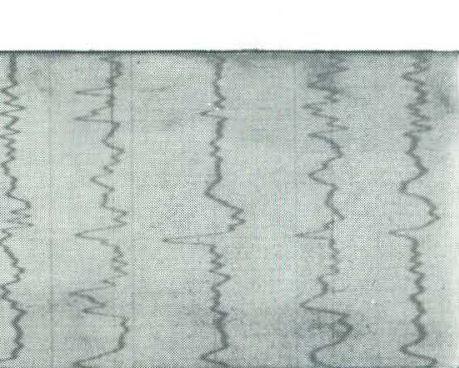

$$
I^{\prime \prime}=1240 \mu \mathrm{in} / \mathrm{in}
$$

Fig. 6 Oscillograph Traces Showing the Effect of the Fluidized Bed, Temperature and Air Flow on Tube Strain

D. $\mathrm{NaK}$ temperature $=700^{\circ} \mathrm{F}$ Air flow $=32,000 \mathrm{SCFH}$ With Bed

Air flow $=32,000 \mathrm{SCFH}$ NaK temperature $=950^{\circ} \mathrm{F}$
B. With Bed

Air flow $=16,000 \mathrm{SCFH}$

NaK temperature $=140^{\circ} \mathrm{F}$


$I^{\prime \prime}=1240 \mu \mathrm{in} / \mathrm{in}$ 


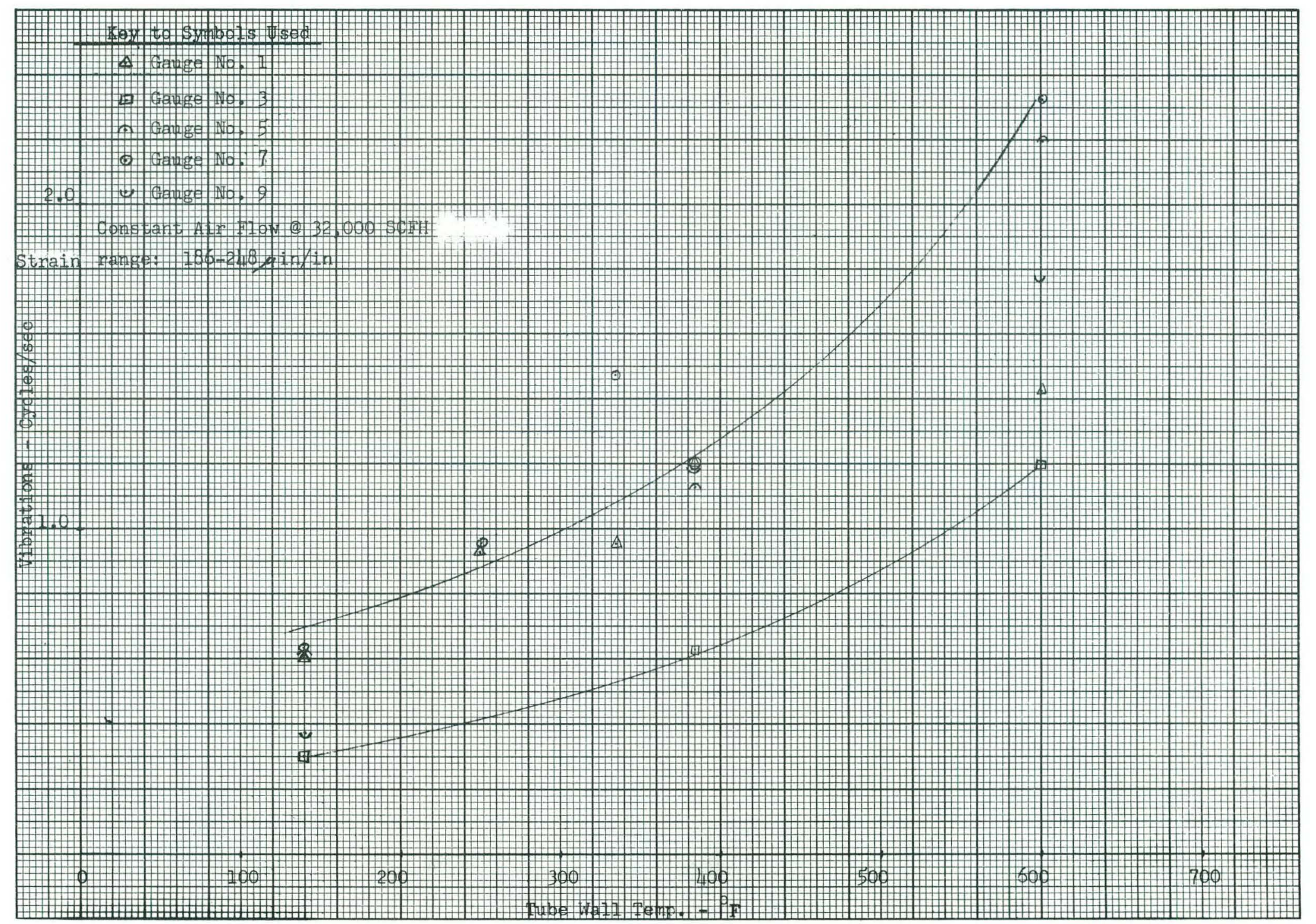

Fig. 7 Temperature vs. Vibration Intensity 




Fig. 8 Temperature vs. Vibration Intensity 


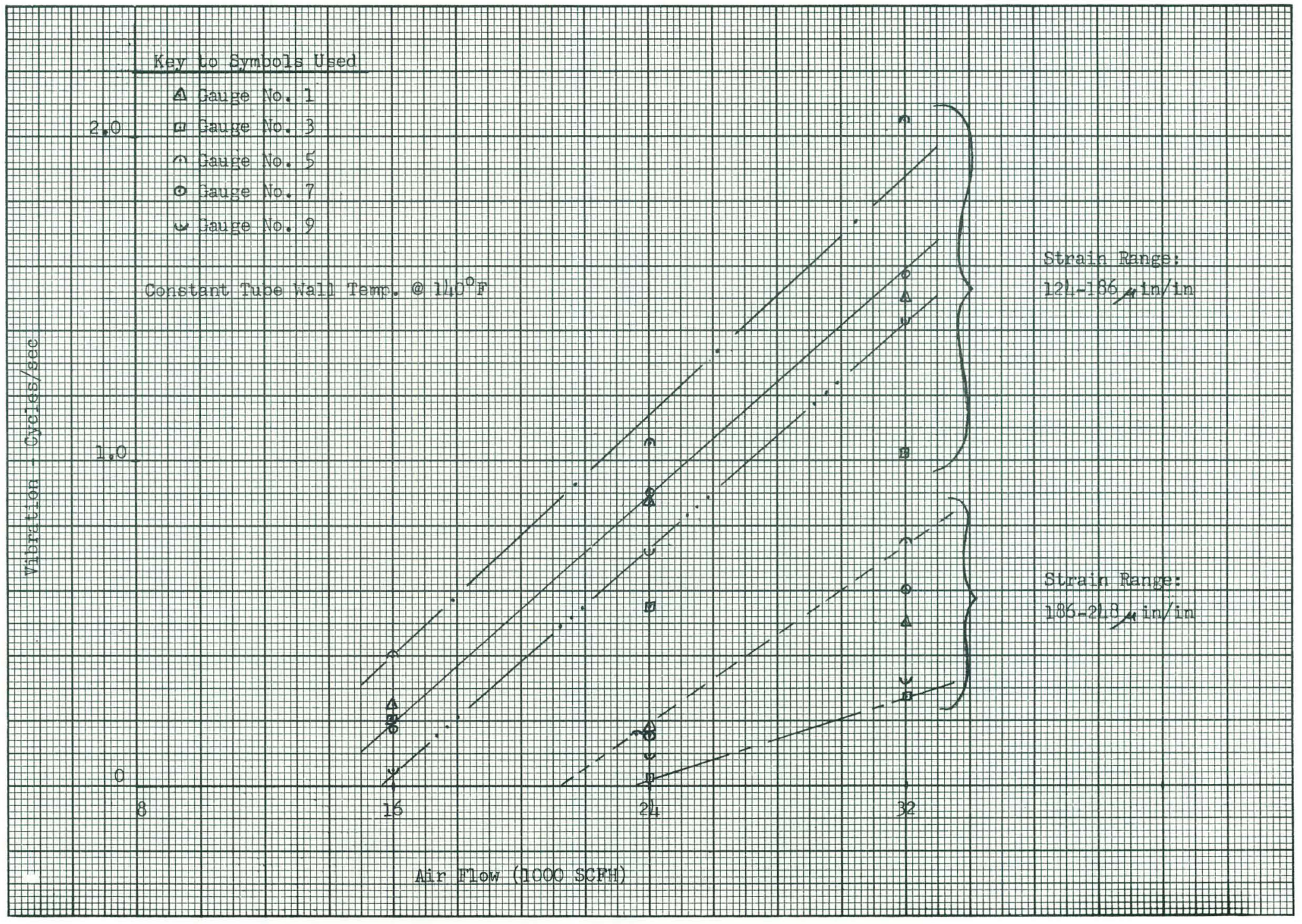

Fig. 9 A1r Flow vs. Vibration Intensity 


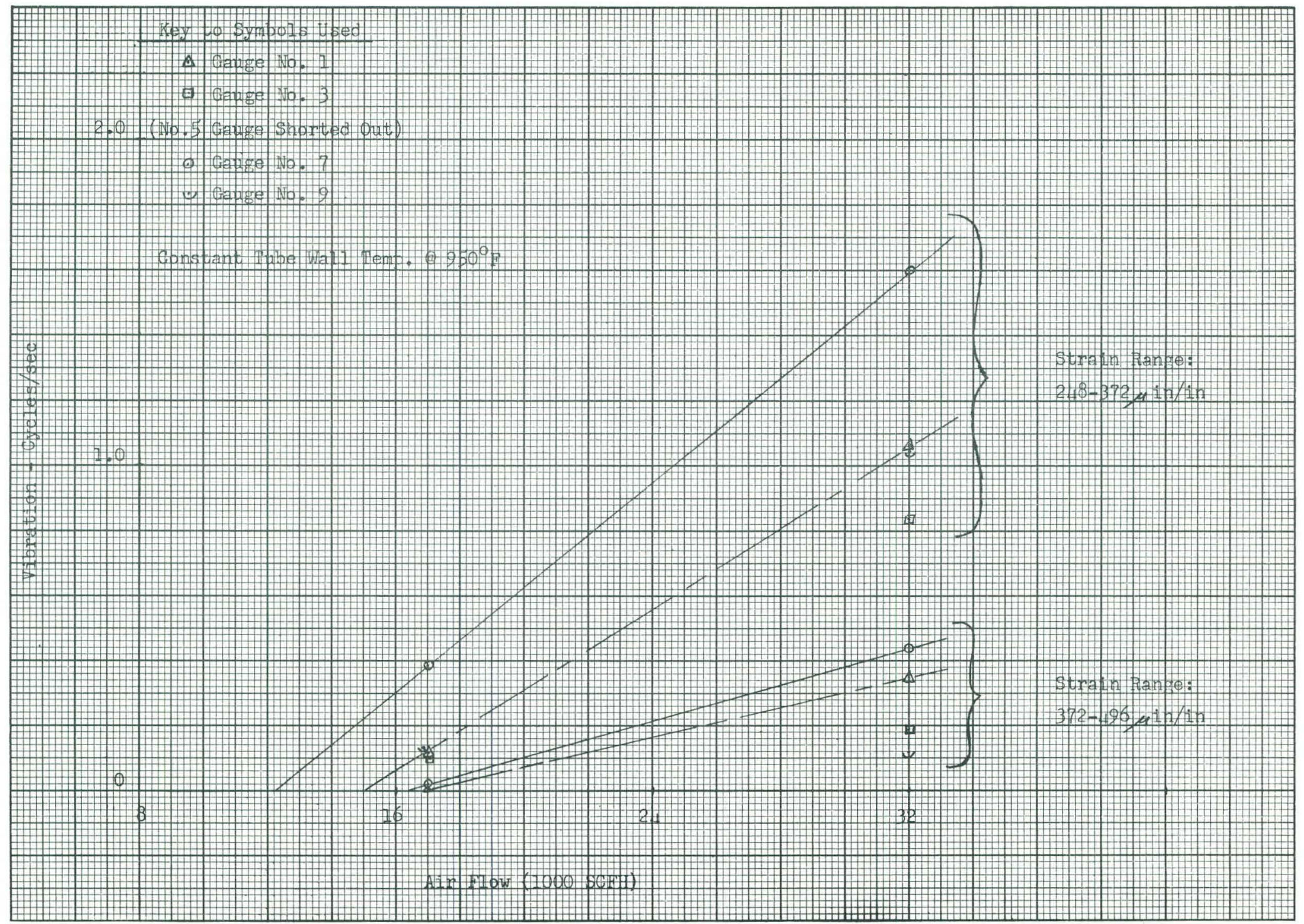

Fig. 10 Air Flow vs. Vibration Intensity 


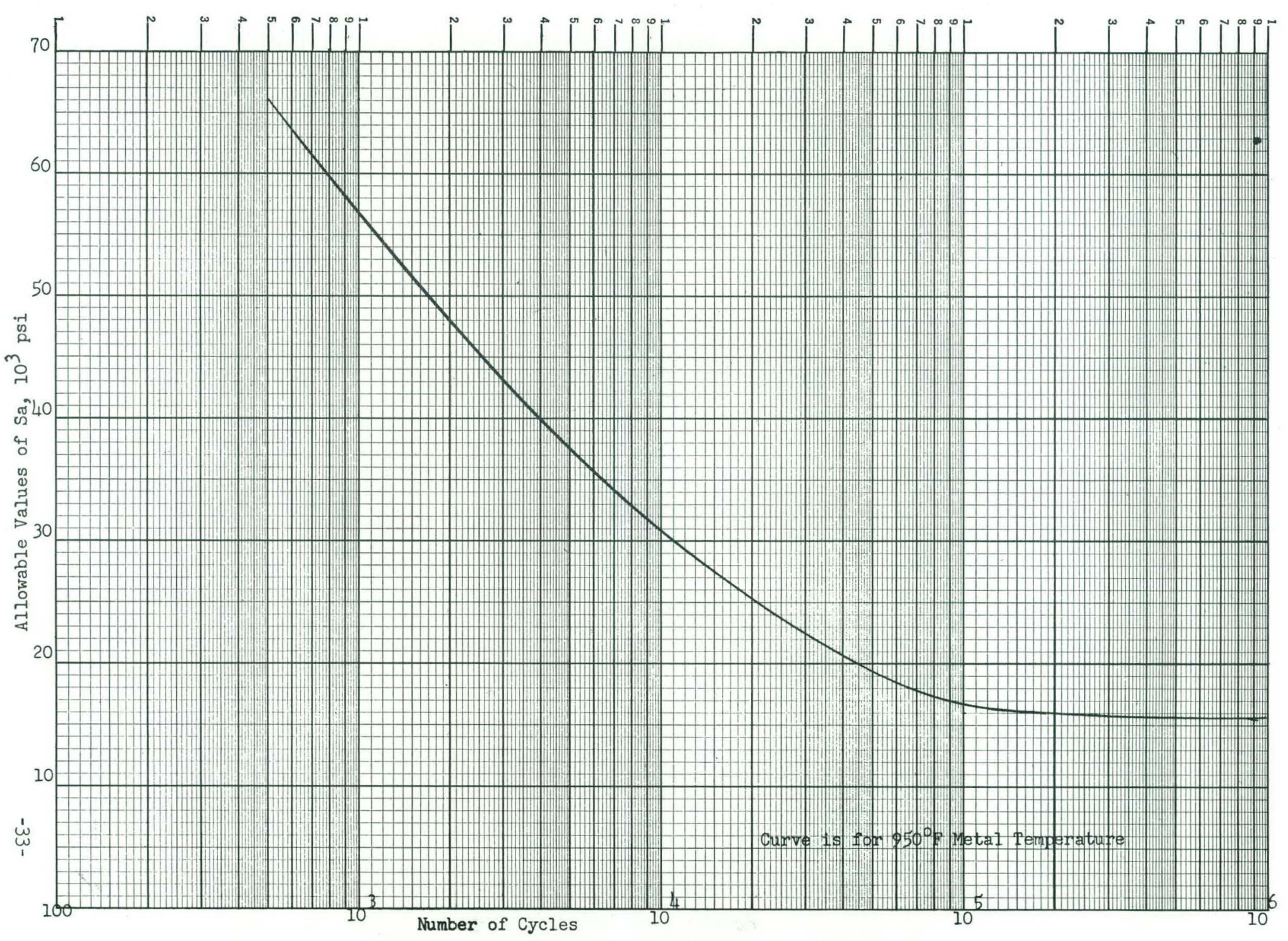

Fig. 11 Design Fatigue Strength Curve 


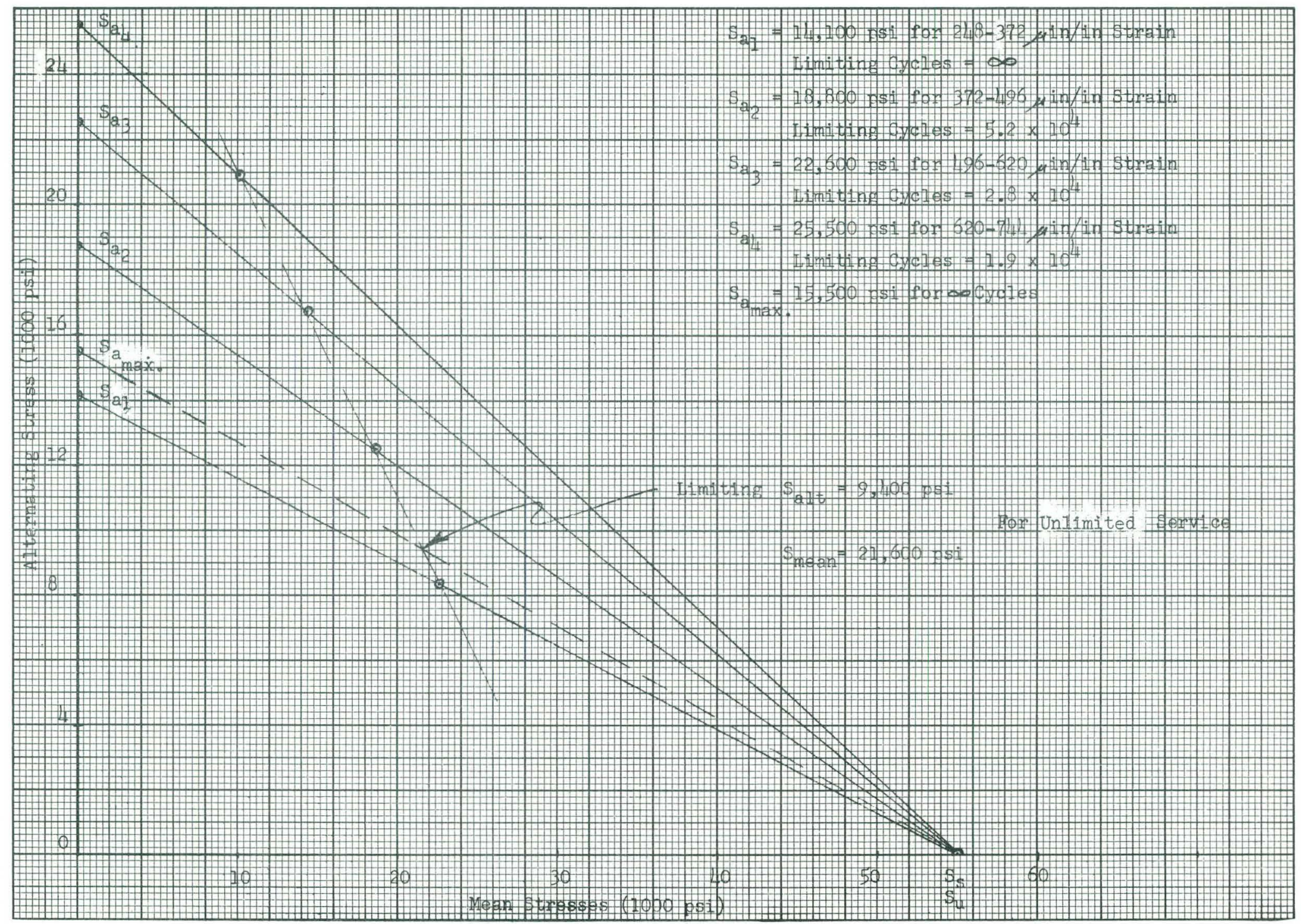

Fig. 12 Fatigue Diagram for $950^{\circ} \mathrm{F}$ Tube Temperature 
